\title{
THE OPTIMALLY MOBILE MUSLIM EXPERTS IN THE SERVICE OF THE UMMAH
}

\author{
S.A. MUYIBI AND M.S. JAMI \\ Department of Biotechnology Engineering, Faculty of Engineering, \\ International Islamic University Malaysia, \\ Jalan Gombak, 53100 Kuala Lumpur, Malaysia. \\ suleyman@iium.edu.my
}

\begin{abstract}
This paper presents a proposal on how the Muslim Experts made up of Academics, Professionals and Entrepreneurs can be made optimally mobile to utilize their Allah endowed resources to serve the Ummah and mankind more efficiently and effectively as well as being key players in a world which has become a "Global Village". Some case studies are presented to illustrate some of the major problems facing the Muslim Ummah today in not being able to utilize optimally the human as well as material resources endowed to us by Allah to enable us fulfill our role as the "best of Ummah" created for the benefit of mankind and vicegerent of Allah. This proposal includes the setting up of an International Organization of Optimally Mobile Muslim Experts (IOOMME). It is envisaged that IOOMME will have a Talent Bank which will be a database on Muslim Academics and Professionals living and working in both Muslim and non-Muslim countries with detailed information about the experts, their areas of expertise and products developed etc. Furthermore professional resource centers which will be land-based as well as cyberspace or virtual based will be setup made up of published information (journals, technical reports) and specialized research equipment/facilities available in Muslim nations where Muslim Academics and Professionals can have access to for their use as well as for developing upcoming Muslim Academics and Professionals. It is envisaged that Muslim nations will create the enabling environment through entry visa and professional short visit regulations for Muslim academics and professionals to use their Sabbaticals, annual vacations, study/research leave, professional short visits etc. academic/ professional staff exchange to go to Muslim nations to render their service to the Ummah.
\end{abstract}

ABSTRAK: Kertas ini membentangkan cadangan bagaimana kumpulan Pakar Islam yang terdiri daripada kalangan ahli akademik, golongan profesional dan para usahawan dibentuk agar dapat berfungsi secara optimum. Kepakaran yang dikurniakan Allah wajar digunakan untuk berkhidmat kepada umat manusia secara lebih cekap dan berkesan disamping memainkan peranan penting memandangkan dunia kini telah dikenali sebagai "Perkampungan Global". Beberapa kajian kes telah dibentangkan untuk menjelaskan beberapa masalah utama umat Islam hari ini perlu lalui. Apabila kita tidak menggunakan secara optima tenaga serta sumber kekayaan yang diberikan Allah, maka kita tidaklah dapat menunaikan peranan sebagai "umat terbilang" dengan sepenuhnya, yang diwujudkan demi manfaat manusia serta khalifah Allah. Antara cadangannya termasuklah menubuhkan Organisasi Sedunia Pakar Islam Optima Bergerak (International Organization of Optimally Mobile Muslim Experts (IOOMME). IOOMME dijangkakan akan mempunyai Bank Bakat di mana ia akan mempunyai pangkalan data ahli akademik Islam dan profesional yang tinggal dan bekerja di negara Islam dan negara bukan Islam dengan maklumat terperinci mereka, bidang kepakaran masing-masing, produk yang telah dihasilkan dan sebagainya. Tambahan pula, pusat sumber profesional yang nyata dan juga di alam siber yang akan ditubuhkan terdiri daripada maklumat 
bercetak (seperti jurnal dan laporan teknikal) dan alatan/kemudahan penyelidikan yang khusus. Semua kemudahan ini boleh didapati di negara-negara Islam di mana ahli akademik dan profesional Islam boleh mengakses demi kepentingan mereka dan juga untuk kemajuan para akademik dan profesional Islam akan datang. Negara-negara Islam dijangkakan dapat menyediakan kemudahan menerusi visa masuk dan pas lawatan singkat profesional untuk ahli akademik dan profesional Islam dengan menggunakan cuti sabatikal, cuti tahunan, cuti sambil belajar/penyelidikan, lawatan singkat profesional mereka dan sebagainya. Dalam tempoh ini mereka dapat pergi ke negara-negara Islam lain untuk berkhidmat kepada umat Islam di negara-negara tersebut.

KEYWORDS: Muslim academician; professional; talent bank; optimally mobile; service Ummah; resource centers

\section{INTRODUCTION}

The Islamic concept of knowledge $\square$ ilm $\square$ must form the basis of the theoretical and institutional structure of education in Islam. In other words, what makes education truly Islamic is the fact that it is based on a genuinely Islamic notion of knowledge. The concept of ilm, as has been argued forcefully in recent years by numerous Muslim scholars, integrates the pursuit of knowledge with values, envelopes factual insight with metaphysical concerns, and promotes an outlook of balance and genuine synthesis. This is the ultimate difference between the western notion of knowledge, which keeps "knowledge" and "values" in two separate compartments, and does not appreciate any form of knowledge that is not gained by sense perception. The integral world-view of Islam, on the other hand, furnishes us with a number of concepts which, when operationalized and actualized in all their sophistication at various levels of society and civilization, yield an integrated infrastructure for the distribution of knowledge. In addition to the core concept of Tawheed, at least five other Islamic concepts - of ilm (knowledge), Adl (justice), Ibadah (worship) Khilafah (trusteeship), Istislah (social welfare) - have a direct bearing on education to be pursued in the true Islamic spirit. The all-embracing Qur'anic concept of $\mathrm{ilm}$ shaped the outlook of the Muslim people right from the beginning of Islam in Arabia. Islam actually made the pursuit of knowledge a religious obligation: by definition, to be a Muslim is to be deeply entrenched in the generation, production and dissemination of knowledge [1].

There is a strong consensus that deficiency in Muslim human capital is a major cause of Islamic countries remaining poor. To render matters worse, when reasonable quantities of human capital are formed, quite a significant number are lost due to migration leakage. No wonder then that the concern has been to contain the leakage. In the words of a recent World Development Report: "Can something be done to stop the mass departure of trained workers from poorer countries? [2]"

Are the Muslim World today contented to be in the present status quo in which the systems in trade, education, social and culture, communication, finance, development and security and defense, are all intelligently dominated, manipulated, distorted and unfairness dealings by the western powers under globalization [3]?

Even though our national territories are not shrinking, but our minds and thinking are slowly but surely being exploited, disempowered and technologically colonized by the powerful mass media and communication networks. The western mass media are experts in facts manipulation, unfair reporting, bias information and even worst the misunderstood aspects of Islam are being highlighted, and Muslims are branded by western medias by many terms which are not accepted in Islam. 
The balance of trade is forever in the red because of near total reliance on importation of goods and services from the developed countries more than what they should do among themselves. Even though Malaysia exports RM 36.8 billion worth of halal food to OIC countries, that amount is like a drop of water in the ocean when you compare it with the amount of western goods and services that are being imported into OIC countries [4].

When a highly qualified professional chooses to leave his own country for another, he/she does so for one or several reasons. Some of these reasons may be due to legitimate political or economic reasons: peace and security for himself and his family, job satisfaction, better pay and conditions, access to educational opportunities for self and or family, a better quality of life and a challenging environment in which they can thrive and fulfill their potential. Furthermore professionals who trained abroad in certain specialized areas will become redundant because they have no place to practice the expertise they have acquired, in their countries of origin, so they have no option but to stay abroad permanently. There are yet others who returned but because of the lack of systems at their homes, they prefer going back abroad. A number of developed countries have also liberalized their immigration policies for the admission of highly skilled professionals. This paper presents a proposal on how the Muslim Experts made up of Academics, Professionals and Entrepreneurs can be made optimally mobile to utilize their Allah endowed resources to serve the Ummah and mankind more efficiently and effectively as well as being key players in a world which has become a "Global Village".

\section{THE OPTIMALLY MOBILE MUSLIM EXPERTS IN THE SERVICE OF THE UMMAH GLOBALLY}

The optimally mobile expert is that individual or groups of individuals who are committed to put to use their Allah endowed resources to render their services and expertise to the Ummah in particular, mankind and all Allah's creation on earth whenever the need arise to earn the pleasure of Allah only as part of Ibadat. Such individuals or groups of Muslim Academicians, Professionals, and Entrepreneurs shall therefore have the following characteristics or develop these characteristics among others to become optimally mobile.

i) Be Ummatic: This implies that they love the Ummah for the sake of Allah and express their Tawhidic ties with other Muslims through networking, sharing of resources etc.,

ii) Be Patriotic: This implies they should love their respective countries and contribute to its development. They should maintain a trusted relationship with political leaders in their parent countries.

iii) Be ethical and principled: This implies the application of Islamic values, moral, and ethics in all they do throughout their lives on this earth. They should therefore be always conscious of the fact that as Muslims we find out why and how of Allah's endowed resources and use it for the benefit of the Ummah in particular and all Allah's creation both animate and inanimate in general. This will enable all humankind to do Ibadat efficiently and effectively in ways shown by our beloved Rasul Muhammad (SAW) required by Allah to please Allah. This will then Insha Allah make their role as vicegerent of Allah to be acceptable to Allah. Knowledge is the unique faculty of mankind and is an integral part of their personality and their being. It is knowledge that qualifies mankind to be viceroy 
of Allah our Rabb and entitle mankind to command the respect and allegiance even of angels of Allah.

iv) Be strong academically, intellectually, and professionally: This implies that they should be competent, be knowledgeable, and consider the application of their knowledge and expertise as Amal which is part of Ibadat and therefore compulsory.

v) Be holistic in approach to solving problems: This implies seeing the world as being interconnected spiritually, economically, politically, technologically, environmentally etc.

vi) Be cooperative: This implies cooperation with Muslims and friendly/sympathetic non-Muslim individuals and organizations through networking. Positive interpersonal relations should be observed and promoted through implanting principles of brotherhood and compassion among those they come in contact with.

\section{STRATEGIES FOR THE SETTING UP OF INTERNATIONAL ORGANISATION OF OPTIMALLY MOBILE MUSLIM EXPERTS (IOOMME)}

In order to create the enabling environment for the Ummah to have optimally mobile Muslim Academicians, Professionals and Entrepreneurs, who will provide solutions to the Ummatic conundrum in all fields of human endeavor like technology, science, law, commerce, as well as meeting the challenges posed by globalization being imposed on the Ummah in particular and mankind in general some strategies are proposed to achieve these objectives.

Setting up a global organization to be known as International Organisation of Optimally Mobile Muslim Experts (IOOMME). This organization will Insha Allah be based in Malaysia located at the International Islamic University Malaysia (IIUM) as the secretariat. It is envisaged that IOOMME will have branches in all OIC countries as well as non-Muslim nations with large concentration of immigrant and revert Muslim populations.

IOOMME will develop a website for the Muslim Ummah worldwide which will contain some of the following information;

A) Talent Bank which will contain information about Muslim Academics, Professionals, and Entrepreneurs, their location, and area of expertise etc. available on line with access based on permission being granted by the website manager or system administrator in consultation with the Academician or Professional.

B) Information about facilities e.g. research institutes/centers, specialized institutions like specialist hospitals, technology parks etc in Muslim nations which can be made available for use by Muslim Academicians, Professionals, and Entrepreneurs in the service of the Ummah and mankind.

C) Through cooperation and networking among Muslim nations, there will be the urgent need to create the enabling environment for easy mobility of Muslim Academicians, Professionals and Entrepreneurs from one nation to another to render their services to one another for the benefit and development of the 
Ummah in particular and mankind in general. These objectives can be achieved through some of the following actions:

i. Introduction of a common K-passport in all Muslim Nations which will have in built facilities like relaxed work permit, entry visa, and other immigration requirements for Muslim Academicians. Professionals and Entrepreneurs . This will encourage Brain Gain from the present Brain Drain of Muslim Academics and Professionals from Muslim nations to non-Muslim nations.

ii. Relaxed entry visa, work permit etc. for ease of mobility of Muslim Academics Professionals and Entrepreneurs from non-Muslim Nations.Encouragement of migration of Muslim Academics, Professionals and Entrepreneurs who are citizens of Muslim nations as well as those from non-Muslim nations with large concentration of immigrant and revert Muslim populations to get long term temporary residency as well as permanent residency in Muslim nations whose proximity will enable them to render more effective service/ expertise to the Ummah.

iii. Muslim Academics and Professionals should be encouraged to go for their sabbaticals, study/research leave, professional short visit, annual vacations etc. There should be programs like academic staff/professional exchanges, external examiners, postgraduate training, receiving Muslim students in their laboratories etc.

iv. There should be access across all Muslim nations for the use of their pooled resources like research institutes/centers, specialized institutions like specialist hospitals, technology parks, data banks, library resources etc.

v. Setting up of Waqf funds in Muslim nations for research and development, provision of travel grants for visiting scholars and professionals etc.

vi. Provision of competitive salary and fringe benefits.

vii. Consultancy and applied research and technology development/transfer in public research institutes.

viii. Participating in training or research via the network and initiating research and commercialization of products.

ix. Facilitating business contacts.

x. Encourage Muslim Academics and Professionals to author books based on Islamic principles which will imply a paradigm shift, and publication of scholarly, professional, and application oriented papers in journals.

\section{CONCLUSION}

In conclusion, even though the brain drain is not a recent phenomenon, it has caused serious developmental problems in Muslim countries over the last few years. The Muslim Ummah is losing more skilled people every year. A project like IOOMME can be invaluable in recapturing some of the lost skills. However, we realize that the success of IOOMME depends on amongst other factors, the willingness and commitment of the expatriates, getting trusted relationships with political leaders etc. It is also important to go beyond just setting up the network, but ensuring that it is self-sustainable and a call from Allah (SWT) to all Muslim Academics and Professionals that Allah (SWT) will ask every 
one of us what we did with our knowledge and talent for the service of the Ummah in particular and mankind in general.

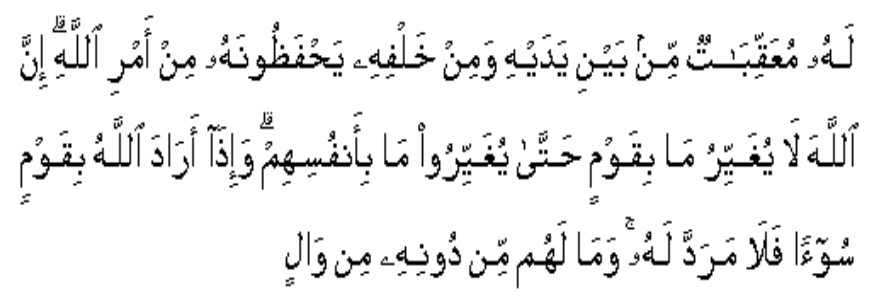

"For him( each ) person, there are angels in succession, before and behind him. They guard him by the Command of Allah. Verily Allah will not change the ( good) condition of a people as long as they do not change their state ( of goodness) themselves ( by committing sins and by being ungrateful and disobedient to Allah). But when Allah Wills a people's punishment, there can be no turning back of it, and they will find besides Him no protector" [5].

\section{REFERENCES}

[1] S. Abdul Latif (1977) "The basis of Islamic Culture" I darah -I- Adabiyat Delhi, India.

[2] World Bank, 1995.World Development Report 1995. Oxford University Press, New York.).

[3] S. A. Muyibi And Abu Zahrin Bin Abu Bakar "THE United Muslim Ummah (TUMU)". International Conference on Muslim Unity in the $21^{\text {st }}$ Century - Opportunities and Challenges” Organised by International Institute for Muslim Unity, 1 - 2 October 2003 Kuala Lumpur, Malaysia Proceedings Vol 1. pp 7 - 34

[4] ""www.arabicnews.com/ansub/Daily/ Day/010227/2001022720.html""

[5] The Holy Quran: English Translation of the meanings and commentary. King Fahd Complex for Printing of Holy Quran, Madina K. S. A 